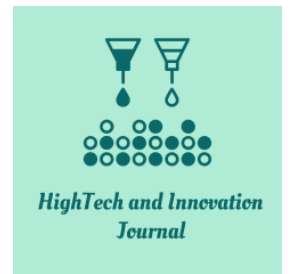

ISSN: 2723-9535

\title{
Development of Starter Culture for the Improvement in the Quality of Ogiri, a Food Condiment
}

\author{
O. A. Olaoye ${ }^{1 *} \oplus$, J. C. Ohuche ${ }^{2}$, A. C. Nwachukwu ${ }^{1}$, U. V. Nwaigwe ${ }^{1}$ \\ ${ }^{l}$ Department of Food Science and Technology, Michael Okpara University of Agriculture, Umudike, Abia State, Nigeria. \\ ${ }^{2}$ Department of Microbiology and Brewing, Nnamdi Azikiwe University, Awka, Anambra State, Nigeria.
}

Received 09 December 2021; Revised 21 January 2022; Accepted 25 January 2022; Published 01 March 2022

\begin{abstract}
The objective of the present study was to isolate Lactic Acid Bacteria (LAB) from ogiri, a Nigerian fermented vegetable product, with the primary focus of selecting suitable isolates as candidates for starter cultures for use in possible improvements in the quality of the product. LAB was isolated from ogiri using phenotypic methods and then subjected to technological tests to evaluate its suitability as a starter culture. Based on their considerable technological properties, two isolates of $\mathrm{LAB}$ were selected as candidates for starter cultures. The starter cultures were inoculated at $10^{3} \mathrm{CFU} / \mathrm{g}$ during the production of ogiri, while un-inoculated samples served as a control. The ogiri samples were stored for nine days, within which samples were taken for microbial and proximate analyses. Four LAB isolates were isolated and identified phenotypically from ogiri procured from a commercial market, including Lactobacillus acidophilus, Lactobacillus fermentum, Enterococcus sp. and Lactobacillus plantarum. The species of Lactobacillus displayed the usual cell shapes of rods when examined under the microscope, which is typical of most members of the genus. The cells of the Enterococcus sp. were, however, cocci in shape, and this is also typical of members of the genus. The basis of the identification of the LAB isolates was their ability to utilize a wide range of carbon sources in their physiological and biochemical activities. Among the LAB isolates, L. acidophilus, L. fermentum produced less than 0.35 and $0.024 \mathrm{mg} / \mathrm{l}$ of acetic acid and hydrogen peroxide, respectively, and were therefore chosen as starter cultures for the production of ogiri. Inoculated ogiri samples showed reduced counts of coliforms, yeast, and moulds in comparison with their un-inoculated counterparts during storage. Coliform counts increased beyond $10^{5} \mathrm{CFU} / \mathrm{g}$ in the un-inoculated control samples, whereas counts were lower in samples inoculated with L. acidophilus and L. fermentum. Yeast and mould count of $8.110^{6} \mathrm{CFU} / \mathrm{g}$ was recorded as the highest value in the un-inoculated control samples, but the count was generally below $10^{6} \mathrm{CFU} / \mathrm{g}$ in the starter culture inoculated samples. Inoculation with LAB did not have significant difference $(\mathrm{p}>0.05)$ in the proximate compositions of the fermented product. The LAB cultures L. acidophilus and L. fermentum demonstrated considerable control of coliforms and fungi in ogiri. Storage of the fermented product should not exceed 5 days for safety concerns, as an increase in counts of coliforms was recorded beyond this period. No significant difference $(p>0.05)$ was recorded in the proximate compositions of starter culture inoculated ogiri and un-inoculated samples.
\end{abstract}

Keywords: Technological Properties; Ogiri; Lactic Acid Bacteria; Lactobacillus; Enterococcus; Phenotypically, Food Technology.

\section{Introduction}

Ogiri is a fermented condiment, which gives a pleasant aroma to soups and sauces in many countries, especially in Africa and India, where protein calorie malnutrition is a major problem. Fermented condiments have great potential as

* Corresponding author: olaayosegun@yahoo.com

$>$ This is an open access article under the CC-BY license (https://creativecommons.org/licenses/by/4.0/).

(C) Authors retain all copyrights. 
key protein and fatty acid sources, and are good sources of gross energy. Therefore, condiments are basic ingredients for food supplementation, and their socio-economic importance cannot be over emphasized [1]. They constitute a significant proportion of the protein content of diets in rural populations across West Africa, and they are usually introduced in fairly small quantities during cooking because of their strong flavour and aroma characteristics [2]. The production of ogiri involves fermentation during which microorganisms utilize biochemical constituents of the substrate, changing them from one form to another with the aid of microbial enzymes [3]. This process enhances the palatability and increases the protein value, vitamin content, and mineral levels of such foods. It also improves food preservation, food safety, enhances flavour and acceptability, it increases variety in the diet, improves nutritional value, reduces anti-nutritional compounds and, in some cases, improves functional properties [4].

Lactic acid bacteria (LAB) have a GRAS (generally regarded as safe) status, and have been widely used as starters in the production of fermented foods [5]. The ability of LAB to inhibit the growth of undesirable bacteria has been reported, and inhibition may be due to the production of organic acids, hydrogen peroxide, carbon dioxide, acetaldehyde, diacetyl or bacteriocins [6, 7]. Occurrence of LAB such as Lactobacillus fermentum during the production of ogiri has been reported [8]. The authors also noted that L. fermentum was among the principal participants in the fermentation process of the product. Besides L. fermentum, other species of LAB belonging to the genera Streptococcus, Pediococcus, and Leuconostoc have been identified to be associated with the production of ogiri [4, 9].

The association of microorganisms of public health significance has been reported in ogiri. Such microorganisms include species of Staphylococcus, Pseudomonas, Proteus, Escherichia, and Enterobacter [1, 9], some of which belong to the group of coliforms and may be pathogenic in nature. There is therefore a need to contain many of these indicator microorganisms which may pose health risks to consumers of the product, especially through the use of lactic acid bacteria as biological bio-preservatives by exploiting their technological properties. The present study, therefore, is aimed at using LAB isolates as co-cultures in the fermentation process during the production of ogiri from different vegetables, with the primary focus on controlling coliforms in the product.

\section{Materials and Methods}

\subsection{Collection of Samples}

Seeds of castor beans (Ricinus communis), fluted pumkin (Telfairia occidentalis), and melon (Cucumis melo) were purchased from Orieugba market in Umuahia North local government area of Umuahia, Abia State, Nigeria (Figure 1). The seeds were transported in clean plastic containers to the laboratory for processing. Commercial ogiri samples were also obtained from the same source, for the purpose of isolating lactic acid bacteria to be used as starter cultures (after subjecting them to technological assessments) during laboratory preparations of the product.

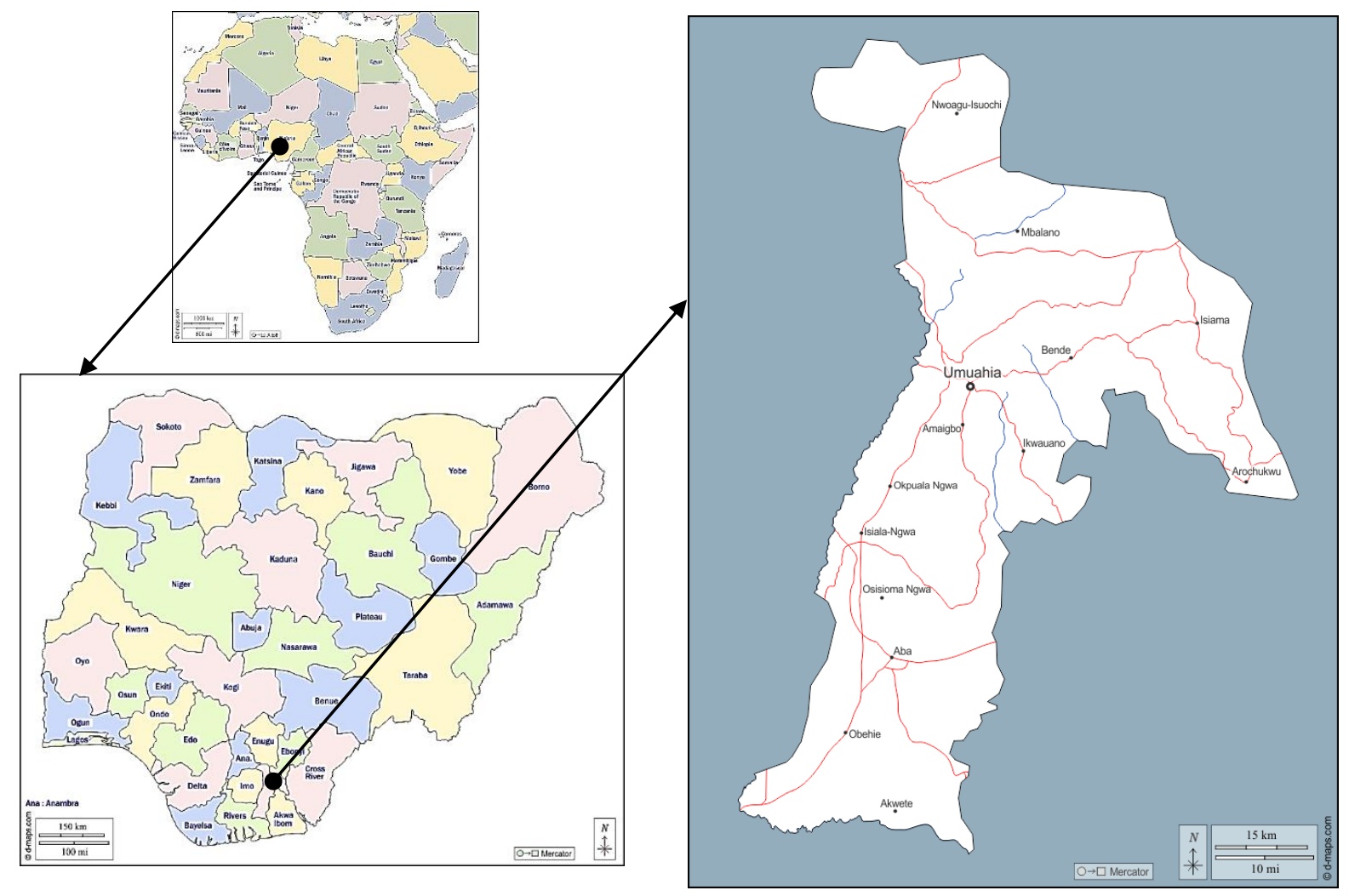

Figure 1. The Location of data collection in Umuahia North, local government area of Umuahia, Abia State, Nigeria 


\subsection{Isolation and Phenotypic Properties of Lactic Acid Bacteria from Ogiri}

Lactic acid bacteria (LAB) were isolated from commercial ogiri using the modified method of Olaoye. Ten grams $(10 \mathrm{~g})$ of ogiri were macerated in $90 \mathrm{ml}$ sterile saline solution $(1 \% \mathrm{w} / \mathrm{v})$. The resulting macerate was plated by spreading $1 \mathrm{ml}$ of it in sterile petri dishes containing deMan Rogossa Sharpe (MRS, Oxoid UK) agar, with the aid of sterile spreaders. The plates were then incubated at $30^{\circ} \mathrm{C}$ for $24 \mathrm{~h}$ inside anaerobic jars. Plates were examined for growth of visible colonies after incubation; colonies that tested negative to catalase test were presumed to be lactic acid bacteria, and picked and sub-cultured repeatedly to obtain pure cultures. Cultures were subjected to Gram staining and microscopic examinations to ascertain purity and cell morphologies. The morphological and biochemical characteristics of the colonies were determined using the method of Stiles and Holzapfel [10] to aid in their identifications; only Gram positive isolates were picked as presumptive LAB isolates and stored on MRS agar slants in the refrigerator (approximately $4^{\circ} \mathrm{C}$ ) for further use.

\subsection{Screening of Lactic Acid Bacteria for Technological Properties}

The lactic acid bacteria isolates were screened for production of organic acids, diacetyl and hydrogen peroxide using the modified methods of Olaoye and Onilude [11]. Evaluations of organic acids (lactic and acetic acids) and diacetyl produced by the LAB isolates were carried out using high performance liquid chromatography and gas chromatography respectively. For the determination of acidification abilities of the strains, the isolates were initially grown in brain heart infusion (BHI) broth and then in sterile reconstituted skim milk supplemented with yeast extract $(3 \mathrm{~g} / \mathrm{l})$ and glucose $(2 \mathrm{~g} / \mathrm{l})$ for two successive sub culturing. Sterile reconstituted skim milk (100 ml) was inoculated with $1 \%(\mathrm{v} / \mathrm{v})$ of a $24 \mathrm{~h}$ activated culture and $\mathrm{pH}$ changes were determined using $\mathrm{pH}$ meters (glass electrode, HANNA instruments, Padova, Italy).

\subsection{Preparation of Ogiri from Seeds of Melon, Fluted Pumpkin and Castor Seeds}

Ogiri samples were prepared separately from the seeds of melon, fluted pumpkin and castor seeds, using traditional methods with some modifications $[4,12]$; the flow chart is represented in Figure 2.

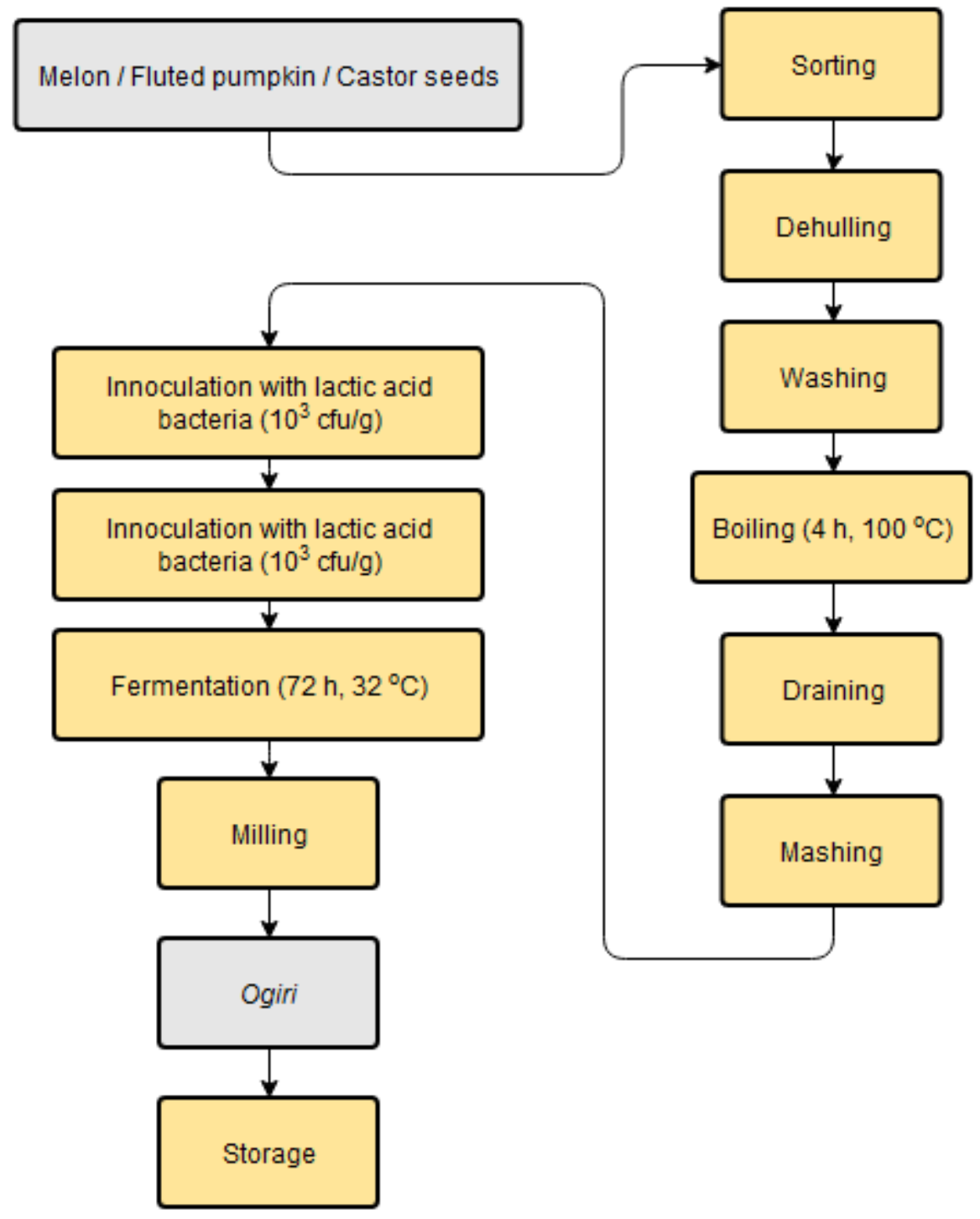

Figure 2. Flow chart for preparation of Ogiri from different vegetable sources 
After preparing the seeds (by removing coats, and through washing with clean water), they were transferred into separate pots and covered completely with water and then boiled. The seeds were subjected to boiling (approximately $4 \mathrm{~h}$ ) to soften and probably reduce anti nutrients in the seeds. The seeds were then drained, mashed and then wrapped in plantain leaves for $72 \mathrm{~h}$ at ambient temperature $\left(\sim 32^{\circ} \mathrm{C}\right)$ for fermentation to take place. For the inoculation of lactic acid bacteria, the mashed seeds were inoculated with isolates of Lactobacillus fermentum and L. acidophilus (inoculum size of $10^{3} \mathrm{CFU} / \mathrm{g}$ ) prior to fermentation.

\subsection{Microbial Enumerations of Ogiri Samples}

The ogiri samples were subjected to microbial enumerations, including yeasts and moulds, and coliforms, using the methods of Olaoye and Onilude [7]. Yeasts and moulds (fungi) were enumerated using Rose Bengal Chloramphenicol Agar (Oxoid, UK), incubated at $25^{\circ} \mathrm{C}$ for $72 \mathrm{~h}$ while MacConkey Agar (Oxoid, UK) was used for coliforms at $37^{\circ} \mathrm{C}$ for $24 \mathrm{~h}$.

\subsection{Proximate Composition of Ogiri Samples}

The proximate composition, including moisture, ash, fat, and protein contents of the ogiri samples were determined using the methods of Association of Official Analytical Chemists [13]. Carbohydrate was determined by difference.

\subsection{Statistical Analysis}

The data obtained, which depended on ogiri samples produced with inoculation of lactic acid bacteria and uninoculated (control) samples were analyzed using the means of three replicates of each sample. Means of data were separated and analyzed using the $t$-test in data analysis functionality of Microsoft Excel 2010 SP2 (version 14.0.7015.1000) to determine differences. Significant differences among samples were determined at $p<0.05$.

\section{Results and Discussion}

In the present report, four lactic acid bacteria $(\mathrm{LAB})$ were isolated and identified through their morphological and biochemical characteristics (Table 1) from ogiri. The identified LAB include; Lactobacillus acidophilus, L. fermentum, L. plantarum and Enterococcus sp. The species of Lactobacillus displayed usual cell shapes of rods when examined under the microscope, which is typical of most members of the genus. The cells of the Enterococcus sp. were, however cocci in shapes, and this is also typical of members of the genus. The basis of identification of the LAB isolates was on their ability to utilize wide range carbon sources in their physiological and biochemical activities [14]. Other authors have reported isolation and identification of LAB from traditional fermented foods. For example, Ukaoma et al. [4] isolated and identified strains of Lactobacillus from ogiri. David and Aderibigbe [9] also reported the isolation and identification of species belonging to various genera of LAB, including Leuconostoc, Streptococcus, Pediococcus and Lactobacillus.

Research findings have suggested that there is increasing attention on the use of naturally occurring metabolites produced by selected lactic acid bacteria (LAB) to inhibit the growth of undesirable microorganisms [5, 15]. LAB growing naturally in foods produce antimicrobial substances such as lactic and acetic acids, diacetyl, hydrogen peroxide and bacteriocins, which could serve vital roles in bio-preservation of foods [16, 17]. While species of the genus Bacillus have been noted as dominant organisms in the production of ogiri by Adebayo and Obiekezie [8] and Ademola et al. [18], same authors observed that certain species of LAB contribute positively to the quality attributes of the fermented product, especially the aroma and flavor.

Table 1. Morphological and biochemical characteristics of the presumptive lactic acid bacteria (LAB) isolates

\begin{tabular}{|c|c|c|c|c|c|c|c|c|c|c|c|c|c|}
\hline Isolates & $\begin{array}{c}\text { Gram } \\
\text { Reaction }\end{array}$ & $\begin{array}{c}\text { Cell } \\
\text { Shape }\end{array}$ & Indole & Citrate & MR & VP & SH & Mannitol & Lactose & Sucrose & Maltose & Catalase & $\begin{array}{c}\text { Probable } \\
\text { Identity }\end{array}$ \\
\hline LAB 1 & + & $\begin{array}{l}\text { Long } \\
\text { Rods }\end{array}$ & - & - & + & - & - & + & + & + & + & - & $\begin{array}{c}\text { Lactobacillus } \\
\text { acidophilus }\end{array}$ \\
\hline LAB2 & + & Rods & - & - & + & - & - & - & + & + & + & - & $\begin{array}{l}\text { Lactobacillus } \\
\text { fermentum }\end{array}$ \\
\hline LAB3 & + & Cocci & - & - & - & - & - & - & - & - & - & - & $\begin{array}{c}\text { Enterococcus } \\
\text { sp. }\end{array}$ \\
\hline LAB4 & + & $\begin{array}{l}\text { Short } \\
\text { Rods }\end{array}$ & - & - & - & - & - & + & + & + & + & - & $\begin{array}{c}\text { Lactobacillus } \\
\text { plantarum }\end{array}$ \\
\hline
\end{tabular}

MR: Methyl red, VP: Voges Prokauer, SH: Starch hydrolysis

In the present study, the four LAB isolates identified from ogiri were subjected to technological assessment in terms of their abilities to produce organic acids (mainly lactic and acetic acids), diacetyl and hydrogen peroxide. From the result of the technological properties (Table 2), Lactobacillus acidophilus and L. fermentum produced reduced 
quantities of hydrogen peroxide and acetic acid; hydrogen peroxide values $(\mathrm{mg} / \mathrm{l})$ of 0.02 and 0.006 were recorded for the former while 0.34 and 0.41 were obtained in terms of acetic acid (mg/l). The least production of hydrogen peroxide and acetic acid concentrations by the two LAB isolates could make them suitable candidates of starter cultures for production of fermented foods such as ogiri, as high production of these metabolites by LAB has been reported to be disadvantageous in fermented foods. Production of high concentrations of hydrogen peroxide, even though has antimicrobial properties, could lead to loss in food qualities, as it can interfere with the organoleptic properties of fermented food products, through undesirable promotion of rancidity and discoloration [19]. The lower concentrations of acetic acids by L. acidophilus and L. fermentum may be attributed to their homo-fermentative nature, as homofermenters have been noted to produce more lactic acids than acetic acids [20]. The author also reported that acetic acid may impart unpleasant taste on food products when compared to lactic acid, thus making the two LAB isolates better candidates of start cultures for production of ogiri, than their other two counterparts.

Table 2. Technological properties of the phenotypically identified lactic acid bacteria isolates

\begin{tabular}{|c|c|c|c|c|c|c|c|c|c|c|c|c|c|c|c|}
\hline \multirow{2}{*}{ Isolates } & \multicolumn{3}{|c|}{$\mathrm{H}_{2} \mathrm{O}_{2}(\mathrm{mg} / \mathrm{l})$} & \multicolumn{3}{|c|}{ Lactic acid (mg/l) } & \multicolumn{3}{|c|}{ Diacetyl (mg/l) } & \multicolumn{3}{|c|}{ Acetic acid (mg/l) } & \multicolumn{3}{|c|}{ pH } \\
\hline & $24 h$ & $48 h$ & $72 \mathrm{~h}$ & $24 h$ & $48 h$ & $72 \mathrm{~h}$ & $24 h$ & $48 h$ & $72 \mathrm{~h}$ & $24 h$ & $48 h$ & $72 \mathrm{~h}$ & $24 h$ & $48 h$ & $72 \mathrm{~h}$ \\
\hline Lactobacillus acidophilus & 0.02 & 0.04 & 0.04 & 0.72 & 0.99 & 1.22 & 0.43 & 0.57 & 0.74 & 0.34 & 0.69 & 1.02 & 4.0 & 4.1 & 3.8 \\
\hline Lactobacillus fermentum & 0.006 & 0.012 & 0.03 & 0.84 & 1.22 & 1.38 & 0.38 & 0.47 & 0.64 & 0.41 & 0.72 & 1.21 & 3.7 & 3.5 & 3.2 \\
\hline Enterococcus sp. & 0.024 & 0.031 & 0.03 & 0.42 & 1.04 & 1.26 & 0.57 & 0.62 & 0.78 & 0.66 & 0.85 & 1.18 & 4.8 & 4.3 & 3.8 \\
\hline Lactobacillus plantarum & 0.06 & 0.062 & 0.064 & 0.62 & 0.68 & 1.18 & 0.46 & 0.58 & 0.61 & 0.62 & 0.90 & 1.26 & 4.4 & 4.0 & 4.0 \\
\hline
\end{tabular}

After careful consideration of the technological properties of the LAB isolates, L. acidophilus and L. fermentum were selected as starter cultures for use during production of ogiri. Some of the key considerations before the choice of the two isolates include reduced productions of acetic acid and hydrogen peroxide and moderate production of lactic acid and diacetyl, which are very vital to competitive exclusion of unwanted organism in foods [11]. Table 3 shows the results of coliform counts in the ogiri samples inoculated with LAB as starter cultures, and uninoculated control samples, during storage. Results indicate that coliforms were generally lower in starter culture inoculated samples than in their uninoculated counterparts. There were slightly higher counts of coliforms as storage progressed, although counts were generally not significant $(p>0.05)$ in the starter culture inoculated samples, except in few cases; however significant differences $(p<0.05)$ were recorded for their uninoculated control counterparts. During storage, the highest coliform count of $5.8 \times 10^{6} \mathrm{CFU} / \mathrm{g}$ was observed on day 9 for the uninoculated control sample. The decrease in counts of coliforms in the starter inoculated samples suggests the protective ability of LAB cultures against coliforms. In the report by Olaoye and Onilude [7] on meat inoculated with LAB cultures in Nigeria, a reduction in coliform counts was noted during storage. The researchers concluded that the LAB used as protective cultures may have produced antimicrobial agent possibly responsible for reduction in coliform counts. Reports of the presence of coliforms and other pathogenic organisms in ogiri produced from melon seeds have been made by other researchers. David and Aderibigbe [9] reported the occurrence of pathogenic organisms, including Pseudomonas aeruginosa, Klebsiella sp., Escherichia coli and Staphylococcus aureus. In a related study, Ogunshe and Olasugba [1] also reported the occurrence of coliforms in some ogiri samples randomly selected from middle-belt and South Western Nigeria. In the present study, the use of L. acidiphilus and L. fermentum may therefore be of public health significance towards combating the occurrence of coliforms, and other organisms in ogiri that may be pathogenic in nature.

Table 3. Coliform counts (log CFU/g) in the ogiri samples during storage

\begin{tabular}{|c|c|c|c|c|c|c|c|c|c|c|}
\hline SD & FPL1 & FPL2 & FPL3 & CSL1 & CSL2 & CSL3 & MSL1 & MSL2 & MSL3 & Control \\
\hline 1 & $2.4^{\mathrm{d}} \pm 0.2 \times 10^{2}$ & $4.4^{\mathrm{b}} \pm 1.2 \times 10^{2}$ & $3.1^{\mathrm{b}} \pm 0.7 \times 10^{2}$ & $3.8^{\mathrm{c}} \pm 0.6 \times 10^{2}$ & $4.2^{\mathrm{c}} \pm 0.5 \times 10^{2}$ & $4.7^{\mathrm{c}} \pm 2.1 \times 10^{2}$ & $3.8^{\mathrm{d}} \pm 0.3 \times 10^{2}$ & $5.4^{\mathrm{b}} \pm 1.1 \times 10^{2}$ & $5.8^{\mathrm{c}} \pm 1.5 \times 10^{2}$ & $1.3^{\mathrm{e}} \pm 0.1 \times 10^{2}$ \\
\hline 3 & $2.7^{\mathrm{bc}} \pm 0.3 \times 10^{3}$ & $4.2^{\mathrm{b}} \pm 1.0 \times 10^{2}$ & $3.8^{\mathrm{a}} \pm 1.5 \times 10^{3}$ & $3.5^{\mathrm{b}} \pm 1.1 \times 10^{3}$ & $3.7^{\mathrm{b}} \pm 1.1 \times 10^{3}$ & $8.2^{\mathrm{c}} \pm 1.6 \times 10^{2}$ & $3.8^{\mathrm{c}} \pm 0.5 \times 10^{3}$ & $5.2^{\mathrm{b}} \pm 1.3 \times 10^{2}$ & $4.7^{b} \pm 0.8 \times 10^{3}$ & $7.9^{\mathrm{d}} \pm 2.3 \times 10^{3}$ \\
\hline 5 & $6.7^{\mathrm{a}} \pm 0.5 \times 10^{3}$ & $3.2^{\mathrm{a}} \pm 0.4 \times 10^{3}$ & $3.3^{\mathrm{a}} \pm 0.3 \times 10^{3}$ & $3.2^{\mathrm{b}} \pm 0.5 \times 10^{3}$ & $3.4^{\mathrm{b}} \pm 0.6 \times 10^{3}$ & $4.0^{\mathrm{b}} \pm 1.9 \times 10^{3}$ & $5.1^{\mathrm{b}} \pm 1.1 \times 10^{3}$ & $3.4^{\mathrm{a}} \pm 0.7 \times 10^{3}$ & $7.7^{\mathrm{a}} \pm 2.3 \times 10^{3}$ & $1.8^{\mathrm{c}} \pm 0.7 \times 10^{4}$ \\
\hline 7 & $3.2^{\mathrm{b}} \pm 0.8 \times 10^{2}$ & $3.5^{\mathrm{a}} \pm 0.5 \times 10^{3}$ & $3.6^{\mathrm{a}} \pm 1.3 \times 10^{3}$ & $3.1^{\mathrm{a}} \pm 0.7 \times 10^{4}$ & $3.0^{\mathrm{a}} \pm 07 \times 10^{4}$ & $3.4^{\mathrm{b}} \pm 0.4 \times 10^{3}$ & $3.7^{\mathrm{a}} \pm 0.7 \times 10^{4}$ & $4.4^{\mathrm{a}} \pm 1.2 \times 10^{3}$ & $9.2^{\mathrm{a}} \pm 1.4 \times 10^{3}$ & $8.8^{b} \pm 2.1 \times 10^{5}$ \\
\hline 9 & $4.9^{\mathrm{b}} \pm 1.2 \times 10^{3}$ & $3.8^{\mathrm{a}} \pm 1.3 \times 10^{3}$ & $3.7^{\mathrm{a}} \pm 0.9 \times 10^{3}$ & $4.2^{\mathrm{a}} \pm 1.4 \times 10^{4}$ & $2.4^{\mathrm{a}} \pm 0.9 \times 10^{4}$ & $2.6^{\mathrm{a}} \pm 0.5 \times 10^{4}$ & $5.7^{\mathrm{a}} \pm 1.9 \times 10^{4}$ & $3.8^{\mathrm{a}} \pm 1.6 \times 10^{3}$ & $8.1^{\mathrm{a}} \pm 0.8 \times 10^{3}$ & $5.8^{\mathrm{a}} \pm 0.9 \times 10^{6}$ \\
\hline
\end{tabular}

Values are means of replicate determinations. Means with different superscripts across columns are significantly different $(p<0.05)$; CFU, colony forming units; SD, storage days; FPL1, ogiri from fluted pumpkin seeds inoculated with Lactobacillus acidophilus; FPL2, ogiri from fluted pumpkin seeds inoculated with L. fermentum; FPL3, ogiri from fluted pumpkin seeds inoculated with mixed cultures of $L$. acidophilus and L. fermentum; CSL1, ogiri from castor seeds inoculated with $L$. acidophilus; CSL2, ogiri from castor seeds inoculated with L. fermentum; CSL3, ogiri from castor seeds inoculated with mixed cultures of L. acidophilus and L. fermentum; MSL1, ogiri from melon seeds inoculated with L. acidophilus; MSL2, ogiri from melon seeds inoculated with L. fermentum; MSL3, ogiri from melon seeds inoculated with mixed cultures of L. acidophilus and L. fermentum

The yeasts and moulds ( $\mathrm{Y} \& \mathrm{M}$ ) count of the ogiri samples are presented in Table 4. From the results, it was observed that $\mathrm{Y} \& \mathrm{M}$ counts $(\mathrm{CFU} / \mathrm{g})$ ranged between $5.5 \times 10^{2}$ and $7.9 \times 10^{3}$ at the beginning of storage. The counts 
generally increased in all samples as storage period progressed. Among the samples inoculated with LAB starter cultures, the highest count of $9.7 \times 10^{5}$ was observed in the sample produced from fluted pumpkin seeds and inoculated with mixed LAB cultures on the last day of storage (day 9). The LAB starter cultures, especially $L$. acidophilus and $L$. fermentum, were noted to exert antagonistic activities on the $\mathrm{Y} \& \mathrm{M}$, especially when used as singly, and the effect was sustained throughout the storage period. This observation was similar to the research investigations reported by Erkmen [21] and Olaoye and Onilude [7]. The former reported reduction in the Y \& M counts in a Turkish sausage after inoculation with LAB strains as protective cultures in comparison with uninoculated control samples, while the latter also made similar findings in meat samples inoculated with LAB cultures. The findings recorded in the present study of the antagonistic activities of the species of Lactobacillus further support the work of Lipinska et al. [22] who reported the antagonistic of some strains of Lactobacillus against yeasts and moulds, including Aspergillus niger, Fusarium latenicum, Geotrichum candidum, Mucor hiemalis and Candida vini. In their research investigation, Lipinska et al. [22] concluded that the antifungal activities of the Lactobacillus strains used could be due to antimicrobial substances produced by them in vitro in the broths employed as growth media.

Table 4. Yeast and moulds counts (log CFU/g) in the ogiri samples during storage

\begin{tabular}{|c|c|c|c|c|c|c|c|c|c|c|}
\hline 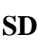 & & & & & & & & & & \\
\hline 1 & & & & & & & & & & \\
\hline 3 & & & & & & & & & & \\
\hline 5 & & & & & & & & & & \\
\hline 7 & & $3.1^{b} \pm 0.5 \times 10^{4}$ & $5.9^{\mathrm{a}} \pm 1.0 \times 10^{5}$ & ${ }^{b} \pm 0.8 \times 10^{4}$ & $2.3^{\mathrm{b}} \pm 0.3 \times 10^{4}$ & $2.3^{\mathrm{b}} \pm 0.6 \times 10^{4}$ & & $2.9^{\mathrm{b}} \pm 0.9 \mathrm{x} 1 \mathrm{C}$ & & $.9^{\mathrm{b}} \pm$ \\
\hline 9 & $.8^{\mathrm{a}} \pm 0.7 \times 10^{4}$ & $9.8^{\mathrm{a}} \pm 0.9 \times 10^{4}$ & $9.7^{\mathrm{a}} \pm 1.3 \times 10^{5}$ & $2.6^{\mathrm{a}} \pm 0.4 \times 10^{5}$ & $1.7^{\mathrm{a}} \pm 0.1 \times 10^{5}$ & $2.1^{\mathrm{a}} \pm 0.3 \times 10^{5}$ & $2.5^{\mathrm{b}} \pm 0.1 \times 10^{3}$ & $2.3^{\mathrm{a}} \pm 0.5 \times 10^{4}$ & $3.2^{\mathrm{a}} \pm 1.1 \times 10^{5}$ & $8.1^{\mathrm{a}} \pm 2.1 \times 10^{6}$ \\
\hline
\end{tabular}

Values are means of replicate determinations. Means with different superscripts across columns are significantly different ( $p<0.05$ ); CFU, colony forming units; SD, storage days; FPL1, ogiri from fluted pumpkin seeds inoculated with Lactobacillus acidophilus; FPL2, ogiri from fluted pumpkin seeds inoculated with L. fermentum; FPL3, ogiri from fluted pumpkin seeds inoculated with mixed cultures of L. acidophilus and L. fermentum; CSL1, ogiri from castor seeds inoculated with L. acidophilus; CSL2, ogiri from castor seeds inoculated with L. fermentum; CSL3, ogiri from castor seeds inoculated with mixed cultures of L. acidophilus and L. fermentum; MSL1, ogiri from melon seeds inoculated with L. acidophilus; MSL2, ogiri from melon seeds inoculated with L. fermentum; MSL3, ogiri from melon seeds inoculated with mixed cultures of L. acidophilus and L. fermentum.

Table 5. Proximate composition of the ogiri samples

\begin{tabular}{|c|c|c|c|c|c|c|c|c|}
\hline Samples & $\begin{array}{c}\text { Dry Matter } \\
(\%)\end{array}$ & $\begin{array}{c}\text { Moisture } \\
\text { Content (\%) }\end{array}$ & $\begin{array}{c}\text { Crude } \\
\text { Protein }(\%)\end{array}$ & $\begin{array}{c}\text { Ether } \\
\text { Extract (\%) }\end{array}$ & $\begin{array}{c}\text { Crude } \\
\text { Fibre (\%) }\end{array}$ & Ash (\%) & $\begin{array}{c}\text { Carbohydrate } \\
(\%)\end{array}$ & $\begin{array}{c}\text { Energy Value } \\
(\%)\end{array}$ \\
\hline FPC & $65.20^{g} \pm 0.14$ & $34.80^{\mathrm{a}} \pm 0.26$ & $22.43^{\mathrm{c}} \pm 0.01$ & $5.70^{\mathrm{e}} \pm 0.02$ & $2.87^{\mathrm{e}} \pm 0.01$ & $2.72^{\mathrm{a}} \pm 0.01$ & $9.48^{\mathrm{e}} \pm 0.16$ & $238.94^{\mathrm{d}} \pm 0.64$ \\
\hline FPL1 & $67.60^{\mathrm{f}} \pm 0.14$ & $32.40^{\mathrm{a}} \pm 0.14$ & $26.82^{\mathrm{a}} \pm 0.03$ & $5.70^{\mathrm{e}} \pm 0.01$ & $2.91^{\mathrm{e}} \pm 0.01$ & $2.72^{\mathrm{a}} \pm 0.03$ & $8.45^{\mathrm{f}} \pm 0.19$ & $276.38^{\mathrm{b}} \pm 0.55$ \\
\hline FPL2 & $69.25^{\mathrm{f}} \pm 0.07$ & $30.75^{b} \pm 0.07$ & $27.98^{\mathrm{a}} \pm 0.01$ & $5.66^{\mathrm{e}} \pm 0.01$ & $2.91^{\mathrm{e}} \pm 0.01$ & $2.75^{\mathrm{a}} \pm 0.02$ & $8.96^{\mathrm{f}} \pm 0.08$ & $286.68^{\mathrm{b}} \pm 0.38$ \\
\hline FPL3 & $68.25^{\mathrm{f}} \pm 0.21$ & $31.75^{\mathrm{b}} \pm 0.21$ & $26.23^{\mathrm{b}} \pm 0.01$ & $5.01^{\mathrm{f}} \pm 0.01$ & $2.91^{\mathrm{e}} \pm 0.01$ & $2.77^{\mathrm{a}} \pm 0.03$ & $9.03^{\mathrm{e}} \pm 0.25$ & $279.29^{\mathrm{b}} \pm 1.09$ \\
\hline CSC & $75.35^{\mathrm{d}} \pm 0.21$ & $24.65^{\mathrm{d}} \pm 0.21$ & $12.60^{\mathrm{f}} \pm 0.03$ & $7.19^{\mathrm{d}} \pm 0.02$ & $3.32^{\mathrm{a}} \pm 0.01$ & $2.62^{\mathrm{b}} \pm 0.01$ & $12.49^{\mathrm{c}} \pm 0.26$ & $237.37^{\mathrm{cd}} \pm 0.74$ \\
\hline CSL1 & $77.70^{c} \pm 0.14$ & $22.30^{\mathrm{e}} \pm 0.14$ & $17.09^{\mathrm{e}} \pm 0.01$ & $6.14^{\mathrm{e}} \pm 0.04$ & $3.34^{\mathrm{b}} \pm 0.01$ & $2.71^{\mathrm{a}} \pm 0.01$ & $10.32^{\mathrm{d}} \pm 0.14$ & $238.30^{\mathrm{cd}} \pm 0.49$ \\
\hline CSL2 & $78.80^{\mathrm{b}} \pm 0.14$ & $21.20^{\mathrm{e}} \pm 0.14$ & $15.83^{\mathrm{e}} \pm 0.03$ & $6.01^{\mathrm{e}} \pm 0.04$ & $3.32^{b} \pm 0.01$ & $2.72^{\mathrm{a}} \pm 0.01$ & $10.79^{\mathrm{d}} \pm 0.18$ & $246.65^{\mathrm{c}} \pm 0.24$ \\
\hline CSL3 & $77.65^{c} \pm 0.14$ & $22.35^{\mathrm{e}} \pm 0.21$ & $16.32^{\mathrm{e}} \pm 0.01$ & $6.32^{\mathrm{d}} \pm 0.03$ & $3.89^{c} \pm 0.01$ & $2.73^{\mathrm{a}} \pm 0.01$ & $10.56^{\mathrm{d}} \pm 0.14$ & $233.00^{\mathrm{d}} \pm 0.99$ \\
\hline MSC & $76.50^{\mathrm{a}} \pm 0.00$ & $23.50^{\mathrm{f}} \pm 0.28$ & $16.26^{\mathrm{e}} \pm 0.01$ & $10.04^{\mathrm{a}} \pm 0.02$ & $2.28^{\mathrm{d}} \pm 0.01$ & $2.02^{\mathrm{c}} \pm 0.01$ & $17.24^{\mathrm{a}} \pm 0.29$ & $303.87^{\mathrm{a}} \pm 1.03$ \\
\hline MSL1 & $78.40^{\mathrm{b}} \pm 1.14$ & $21.60^{\mathrm{e}} \pm 0.14$ & $20.05^{\mathrm{d}} \pm 0.04$ & $9.01^{\mathrm{b}} \pm 0.02$ & $2.23^{\mathrm{b}} \pm 0.01$ & $2.01^{\mathrm{b}} \pm 0.01$ & $15.91^{\mathrm{b}} \pm 0.19$ & $283.23^{\mathrm{b}} \pm 0.53$ \\
\hline MSL2 & $70.85^{\mathrm{e}} \pm 0.07$ & $29.15^{\mathrm{c}} \pm 0.07$ & $19.40^{\mathrm{d}} \pm 0.03$ & $8.01^{\mathrm{c}} \pm 0.03$ & $2.55^{\mathrm{c}} \pm 0.04$ & $2.12^{\mathrm{b}} \pm 0.02$ & $12.27^{\mathrm{c}} \pm 0.01$ & $253.29^{\mathrm{c}} \pm 0.38$ \\
\hline MSL3 & $71.45^{\mathrm{e}} \pm 0.07$ & $28.55^{\mathrm{c}} \pm 0.26$ & $21.92^{\mathrm{c}} \pm 0.03$ & $7.89^{\mathrm{d}} \pm 0.02$ & $2.03^{\mathrm{b}} \pm 0.03$ & $2.72^{\mathrm{a}} \pm 0.01$ & $11.16^{\mathrm{d}} \pm 0.16$ & $277.95^{\mathrm{b}} \pm 0.35$ \\
\hline
\end{tabular}

Values are means of replicate determinations. Means with different superscripts across columns are significantly different $(p<0.05)$; FPC, ogiri from fluted pumpkin seeds; FPL1, ogiri from fluted pumpkin seeds inoculated with Lactobacillus acidophilus; FPL2, ogiri from fluted pumpkin seeds inoculated with L. fermentum; FPL3, ogiri from fluted pumpkin seeds inoculated with mixed cultures of L. acidophilus and L. fermentum; CSL1, ogiri from castor seeds inoculated with $L$. acidophilus; CSL2, ogiri from castor seeds inoculated with L. fermentum; CSL3, ogiri from castor seeds inoculated with mixed cultures of L. acidophilus and L. fermentum; MSL1, ogiri from melon seeds inoculated with L. acidophilus; MSL2, ogiri from melon seeds inoculated with L. fermentum; MSL3, ogiri from melon seeds inoculated with mixed cultures of L. acidophilus and L. fermentum.

Results of the proximate composition (\%) of the ogiri samples indicate that dry matter contents ranged between 65.2 and 86.5, showing varying levels of significant differences $(p<0.05)$ among samples. Moisture content ranged from 21.20 to 34.80 . The values recorded for moisture in the samples in the present study were similar to those reported by David and Aderibigbe [9]. The highest crude protein and ether extract of 27.98 and 10.04 were recorded for ogiri samples made from fluted pumpkin that was inoculated with L. fermentum and un-inoculated melon seed, respectively [23, 24]. In terms of crude fiber, ogiri samples produced from castor seeds had higher values than their counterparts from fluted pumpkin and melon seeds, a value of 3.89 was recorded for a sample from castor seed inoculated with mixed LAB cultures. The highest content of ash (2.75) was recorded for an ogiri sample obtained 
from a fluted pumpkin that was fermented with L. fermentum, while the lowest value of 2.02 was obtained for an ogiri sample from an un-inoculated melon seed. The values of the crude fibers and ash in the ogiri samples obtained in this study show correlation to those reported by David and Aderibigbe [9] and Nnennaya et al. [25] in ogiri made from melon seed and sandbox seed. Generally, inoculation with LAB starter cultures did not significantly affect the proximate compositions of the ogiri samples, though there were variations in the values of the respective proximate parameters, depending on the type of vegetable used.

\section{Conclusion}

In conclusion, the use of LAB starter cultures in this study demonstrated considerable control of coliforms and fungi in ogiri; the effect was more noticeable in samples inoculated with L. acidophilus and L. fermentum. However, based on the results of the microbial analysis, it is suggested that when ogiri is produced using LAB as starter cultures, storage should be limited to a maximum of five (5) days in order not to compromise safety, as an increase in counts of coliforms was recorded beyond this period. Furthermore, the inoculation of LAB as starter cultures in the production of ogiri had no pronounced significant difference in the proximate compositions of the fermented product.

\section{Declarations}

\subsection{Author Contributions}

Conceptualization, O.A.O. and U.V.N.; methodology, O.A.O.; software, O.A.O.; validation, O.A.O., J.C.O., A.C.N. and U.V.N.; formal analysis, U.V.N.; investigation, O.A.O.; resources, O.A.O.; data curation, U.V.N.; writing — original draft preparation, O.A.O.; writing — review and editing, O.A.O.; visualization, O.A.O.; supervision, O.A.O.; project administration, O.A.O.; funding acquisition, U.V.N. All authors have read and agreed to the published version of the manuscript.

\subsection{Data Availability Statement}

The data presented in this study are available in article.

\subsection{Funding}

The authors received no financial support for the research, authorship, and/or publication of this article.

\subsection{Institutional Review Board Statement}

Not Applicable.

\subsection{Declaration of Competing Interest}

The authors declare that they have no known competing financial interests or personal relationships that could have appeared to influence the work reported in this paper.

\section{References}

[1] Ogunshe, A. A. O., \& Olasugba, K. O. (2008). Microbial loads and incidence of food-borne indicator bacteria in most popular indigenous fermented food condiments from middle-belt and southwestern Nigeria. African Journal of Microbiology Research, 2(12), 332-339.

[2] Adedeji, B. S., Ezeokoli, O. T., Ezekiel, C. N., Obadina, A. O., Somorin, Y. M., Sulyok, M., Adeleke, R. A., Warth, B., Nwangburuka, C. C., Omemu, A. M., Oyewole, O. B., \& Krska, R. (2017). Bacterial species and mycotoxin contamination associated with locust bean, melon and their fermented products in south-western Nigeria. International Journal of Food Microbiology, 258, 73-80. doi:10.1016/j.ijfoodmicro.2017.07.014.

[3] ODUNFA, S. A. (1985). Microbiological and Toxicological Aspects of Fermentation of Castor Oil Seeds for Ogiri Production. Journal of Food Science, 50(6), 1758-1759. doi:10.1111/j.1365-2621.1985.tb10587.x.

[4] Ukaoma, A. A., M.O., N., Adjeroh, L., Ezeanowai, C. F., Iwu, I. C., \& Duru, M. Comparative study on microbial loads of fermented castor oil seeds (Ricinus communis) and melon seeds (Citrullus vulgaris. International Journal of Science and Research, 8(8), 83-89.

[5] Onilude, A. A., Sanni, A. I., Olaoye, O. A., \& Ogunbanwo, S. T. (2002). Influence of lactic cultures on the quality attributes of tsire, a West African stick meat. World Journal of Microbiology and Biotechnology, 18(7), 615-619. doi:10.1023/A:1016864100609.

[6] Helander, I. M., Von Wright, A., \& Mattila-Sandholm, T. M. (1997). Potential of lactic acid bacteria and novel antimicrobials against gram-negative bacteria. Trends in Food Science and Technology, 8(5), 146-150. doi:10.1016/S0924-2244(97)01030-3. 
[7] Olaoye, O. A., \& Onilude, A. A. (2010). Investigation on the potential application of biological agents in the extension of shelf life of fresh beef in Nigeria. World Journal of Microbiology and Biotechnology, 26(8), 1445-1454. doi:10.1007/s11274-0100319-5.

[8] O. Adebayo, F., \& O. Obiekezie, S. (2018). Comparative Assessment of Starter Culture-Fermented Condiments Made from Seeds of Citrullus lanatus (Watermelon). South Asian Journal of Research in Microbiology, 1(1), 1-7. doi:10.9734/sajrm/2018/v1i1705.

[9] David, O. M., \& Aderibigbe, E. Y. (2010). Microbiology and proximate composition of ogiri, a pastry produced from different melon seeds. New York Science Journal, 3(4), 18-27.

[10] Stiles, M. E., \& Holzapfel, W. H. (1997). Lactic acid bacteria of foods and their current taxonomy. International Journal of Food Microbiology, 36(1), 1-29. doi:10.1016/S0168-1605(96)01233-0.

[11] Olaoye, O. A., \& Onilude, A. A. (2011). Quantitative estimation of antimicrobials produced by Lactic Acid Bacteria isolated from Nigerian beef. International Food Research Journal, 18(3), 1155-1161.

[12] Chukwu, M., Ezeagwula, C. G., Nwakaudu, A. A., Oti, W., \& Anyaogu, I. (2020). Microbial Loads of Ogiri-Ahuekere Condiment Produced From Groundnut Seed (Arachis Hypogaea Linn). SSRN Electronic Journal, 6(1), 114-119. doi:10.2139/ssrn.3517493.

[13] A.O.A.C. (2005). Official Methods of Analysis of. In Analytical Chemistry (18th edn). Association of Official Analytical Chemists 52(2), 148. doi:10.1021/ac50052a726.

[14] Olaoye, O. A., \& Onilude, A. A. (2009). Isolation and biochemical profiles of numerous strains of lactic acid producing bacteria from various parts of a domestic West African goat (Capra Hircus). Australian Journal of Basic and Applied Sciences, $3(2), 460-466$.

[15] Kaban, G., \& Kaya, M. (2006). Effect of starter culture on growth of Staphylococcus aureus in sucuk. Food Control, 17(10), 797-801. doi:10.1016/j.foodcont.2005.05.003.

[16] Olaoye, O., Oniude, A., \& Dodd, C. (2008). Identification of Pediococcus spp. From Beef and Evaluation of Their Lactic Acid Production in Varying Concentrations of Different Carbon Sources. Advances in Natural and Applied Sciences, 2(January), 197-207.

[17] Noordiana, N., Fatimah, A. B., \& Mun, A. S. (2013). Antibacterial agents produced by lactic acid bacteria isolated from Threadfin Salmon and Grass Shrimp. International Food Research Journal, 20(1), 117-124.

[18] Ademola, O. M., Adeyemi, T. E., Ezeokoli, O. T., Ayeni, K. I., Obadina, A. O., Somorin, Y. M., Omemu, A. M., Adeleke, R. A., Nwangburuka, C. C., Oluwafemi, F., Oyewole, O. B., \& Ezekiel, C. N. (2018). Phylogenetic analyses of bacteria associated with the processing of iru and ogiri condiments. Letters in Applied Microbiology, 67(4), 354-362. doi:10.1111/lam.13040.

[19] Ammor, M. S., \& Mayo, B. (2007). Selection criteria for lactic acid bacteria to be used as functional starter cultures in dry sausage production: An update. Meat Science, 76(1), 138-146. doi:10.1016/j.meatsci.2006.10.022.

[20] Olaoye, O. (2014). Technological Properties of Lactococcus lactis subsp. lactis I23 Isolated from Nigerian Beef and Characterization of Bacteriocin Produced by It. British Biotechnology Journal, 4(7), 829-845. doi:10.9734/bbj/2014/11719.

[21] Erkmen, O. (2008). Modeling the effects of sucuk production technique on Listeria monocytogenes, aerobic bacteria and lactic acid bacteria during ripening and storage. Food and Bioproducts Processing, 86(3), 220-226. doi:10.1016/j.fbp.2007.10.002.

[22] Lipińska, L., Klewicki, R., Klewicka, E., Kołodziejczyk, K., Sójka, M., \& Nowak, A. (2016). Antifungal activity of lactobacillus sp. Bacteria in the presence of xylitol and galactosyl-xylitol. BioMed Research International, 2016, 1-8. doi:10.1155/2016/5897486.

[23] Ilango, S., \& Antony, U. (2021). Probiotic microorganisms from non-dairy traditional fermented foods. Trends in Food Science \& Technology, 118, 617-638. doi:10.1016/j.tifs.2021.05.034.

[24] Oguntoyinbo, F. A., Fusco, V., Cho, G.-S., Kabisch, J., Neve, H., Bockelmann, W., ... Franz, C. M. A. P. (2016). Produce from Africa's Gardens: Potential for Leafy Vegetable and Fruit Fermentations. Frontiers in Microbiology, 7. doi:10.3389/fmicb.2016.00981.

[25] Ahaotu Ndidiamaka Nnennaya, Echeta Chinelo Kate, Bede Njideka Evelyn, Awuchi Chinaza Godswill, Anosike Chinwe Linda, Ibeabuchi Chidi Julian, \& Ojukwu Moses. (2020). Study on the nutritional and chemical composition of "Ogiri" condiment made from sandbox seed (Hura crepitans) as affected by fermentation time. GSC Biological and Pharmaceutical Sciences, 11(2), 105-113. doi:10.30574/gscbps.2020.11.2.0115. 